\title{
Effect of Irrigation Water Regime in Presence of Organic or Biological Fertilizer on Olive Trees
}

\author{
Dalal Sary ${ }^{1}$ and Ibrahim Elsokkary ${ }^{2}$ \\ ${ }^{1}$ Calcareous and Sandy Soil, Soil, Water and Environment Institute, Agricultural \\ Research Center, Egypt, ${ }^{2}$ Soil and Water Sciences Department, Faculty of Agriculture, \\ El-Shatby, Alexandria University
}

\begin{abstract}
$\mathbf{T}$ HIS STUDY was carried out during 2010/2011growth season on four olive (Olea europaea L.) varieties: Picual, Aggizi, Mission and Koronieki, grown in calcareous soil at the Horticultural farm of El-Nubariya Agricultural Research Station, Ministry of Agriculture and Land Reclamation Egypt. The experimental of design was in a split-split design (two levels of water regime, four cultivars, six treatments and three replicates). The total numbers of experimental plots used were 144 trees. The main treatments included full and half irrigation water (FIW or HIW) of water requirement (ETpan), the sub-main treatments were the four olive varieties, and the Sub-sub main treatments included NPK fertilizers (100, 75, and 50\% dose) with effective microorganisms (E.M.) or humic acid (H.A.). The objectives of this study were to investigate the response of four olive varieties to variations in the quantity of irrigation water and NPK fertilizers rates in the presence with H.A. or E.M. The obtained results showed positive significant effects due to FIW or HIW, $75 \%$ NPK +EM or $50 \%$ NPK +EM on fruit weight of Picual and Aggizi,while all treatments showed positive significant effects on increasing fruit weight of Mission. However, Koronieki showed no significant response with all treatments. The oil contents in fruits of Picual, Aggizi, Mission and Koronieki showed significant response to $100 \%$ NPK, $75 \%$ NPK +EM, or $75 \%$ NPK +HA treatment under FIW regime. The highest significant chlorophyll contents in leaves of all olive varieties were obtained by FIW with $75 \%$ NPK +EM and $75 \%$ NPK +HA. The N, P and K contents in leaves of the four olive varieties significantly increased as a result of applying all treatments under FIW or HIW regime. In addition, all treatments increased significantly the levels of total $\mathrm{N}$, available $\mathrm{P}$ and available $\mathrm{K}$ in the soil and also soil respiration as a result of the all treatments with FIW or HIW regime.
\end{abstract}

Keywords: Irrigation water regime, Mineral fertilizers, Organic fertilizer, Biological fertilizer, Olive varieties.

\section{Introduction}

Olive (Olea europaea L.) is a major agricultural crop in the Mediterranean Coastal Basin, and it accounts for around 95\% of the world's olive cultivated area. About $90 \%$ of the olive trees are grown for oil production. The olive tree can tolerate different types of stresses, i.e, drought and salinity. The planted area of olive in Egypt reached about 120,000 Fed according to the statistics of the Ministry of Agriculture in 2004. Olive trees are supposed to be cultivated in the newly reclaimed lands (110000 ha) especially at Sinai and Eastern desert (FAO, STAT, 2010). Also, Olive trees are distributed in many areas such as Matrouh, Fayoum, North and South Sinia, North coast regions and Nubariya (Ministry of Agriculture and Land Reclamation, 2011). ElSayed (2013) showed that the Egyptian olive production was about 563,070 tons produced from 137,025 fed according to Ministry of Agric. Statistics (2012).

The chemical composition of olive fruit includes: water $(50 \%)$, protein $(1.6 \%)$, oil $(22 \%)$, carbohydrates $(19 \%)$, cellulose $(5.8 \%)$ and minerals $(1.5 \%)$. The olive tree can survive on very little rainfall $(220 \mathrm{~mm}$ rain per year) and grows on both siliceous and calcareous soils. The minimum water requirement for olive is 
$2,000 \mathrm{~m}^{3} /$ ha / year mainly in late spring and in summer as the fruit increases in size (Bongi and Palliotti, 1994). Most of olive trees of the North Western Coast are growing in soils poor in nutrients. To improve yield and maintain low water consumption, modern olive plantations require modern techniques of irrigation, such as drip irrigation, to support tree production (Marsal et al., 2002). Also, Mohammed and Noori (2008) found significant increases in the fruit yield and quality characteristics by full irrigation. Palese et al. (2010) suggested that the irrigated olive plants showed $76 \%$ production higher than nonirrigated ones. Water stress, early in the growth season, may strongly reduce the yield due to the effect on flowering and fruit set. Moriana et al. (2003) described a non-linear yield response to irrigation with both fruit and oil yield at low irrigation rates. Melgar et al. (2008) showed that yield was increased in irrigated trees compared to non-irrigated ones. Attalla et al. (2011) found that higher rate of irrigation water (60 mm twice/ month) was more effective in increasing the productivity of Manzanillo olive. Cano-Lamadrid et al. (2015) is effective for obtaining better quality of Manzanillo olive and can be good alternative for olive however, production under summer conditions.

Deficit irrigation, in olive trees, commonly occurs with water stressed soil during mid-summer, which if it is not very severe, did not reduce the oil content (Moriana et al., 2003). Increased rate of irrigation water has negative effects on olive oil quality parameters (Dag et al., 2008). However, Patumi et al. (2002) found that olive oil composition did not change with irrigation. On the other hand, Nikbakht et al. (2011) found that the highest and lowest oil percentages were obtained from irrigated by $75 \%$ and $25 \%$ of olive water requirement. Despite the total water requirement of trees $(100 \%)$ were supplied, the extracted olive oil percent was less than treatment of $50 \%$. Shaheen et al. (2011) showed that chlorophyll content in leaves decreased with increasing water stress, while proline was increased the N, P and $\mathrm{K}$ contents in plant leaves were decreased with increasing water stress. Sardans and Penuelas (2005) found that $10 \%$ reduction of soil moisture decreased urease activity by $10-67 \%$. Yousef et al. (2011) indicated that Humic acid +amino acids+ macro elements + trace elements was positively effective for olive growth and production. Fayed (2010a) reported that soil application of manure tea with yeast +humic acid had positive effects on olive fruit yield. El-Sayed (2013) showed that soil applications of $10 \mathrm{~g}$ yeast /tree $+60 \mathrm{~g}$ humic acid/ tree produced the high fruit oil percentage. Rahil and Jabi (2015) found that supplementary irrigation with humic acid application increased the fruit yield and oil yield of olive grown in loamy soil. Effective microorganisms (EM) contain 60 species of microorganisms including: lactic acid bacteria, yeasts, smaller populations of photosynthetic, N-fixing bacteria, fungi and actinomycetes (Higa and Parrj 1994). The E.M. is a commercial biostimulant produced by EMRO Corporation, Okinawa, Japan. The objectives of this study, therefore, were to investigate the growth response of four olive varieties grown in calcareous soil to irrigation water regime in the presence $\mathrm{N}, \mathrm{P}$ and $\mathrm{K}$ fertilizers in combination with Humic acid (HA) or effective microorganisms (EM).

\section{Materials and Methods}

\section{Experimental layout}

Field experiment was carried out during 2010/2011 growing season on four olive varieties; Picual, Aggizi, Mission and Koronieki grown in calcareous soil at the Horticultural farm of ElNubariya Agricultural Research Station in Behera Governorate, Egypt. The chemical and physical properties of experimental soil are shown in Table 1. The experimental layout was complete randomized design (CRD) in a split-split design (two levels of water regime, four cultivars, six treatments and three replicates). The total numbers of experimental plots used were 144 trees. The main treatments included full irrigation water (FIW) with $100 \%$ of water requirement and half irrigation water (HIW) with $50 \%$ of water requirement of the ETpan. The mean value of ETpan was calculated according to the data obtained daily from the pan evapotranspiration and according to climate data (monthly average) of Nubariya Research Station Weather data of the Meteorological Station for the growing season 2010/2011 (Doorenbos and Kassam, 1986 and FAO, 1970). The quantity of water applied for each irrigation event was measured by flowmeter $\left(\mathrm{m}^{3} / \mathrm{fed} / \mathrm{month}\right)$. The Sub-main treatments included the four olive varieties; the Sub- sub main treatments included six different treatments of mineral NPK fertilizers $(100 \%, 75 \%$, and $50 \%)$ of the recommend usual rates of Ministry of Agriculture and Land Reclamation with effective microorganisms (EM) or humic acid (H.A). The olive orchard was fertilized with farmyard 
manure $\left(20 \mathrm{~m}^{3} /\right.$ fed $)$. The source of $\mathrm{N}$ fertilizer was ammonium sluphate $(20.5 \% \mathrm{~N})$, and that of $\mathrm{P}$ was superphosphate $\left(15.5 \% \mathrm{P}_{2} \mathrm{O}_{5}\right)$, while that of $\mathrm{K}$ was Potassium sulphate $\left(48 \% \mathrm{~K}_{2} \mathrm{O}\right)$ which are added as $600 \mathrm{~kg} / \mathrm{fed}$ of $\mathrm{NH}_{4} \mathrm{SO}_{4}, 175 \mathrm{~kg} / \mathrm{fed}$ of $\mathrm{P}_{2} \mathrm{O}_{5}$ and $150 \mathrm{~kg} /$ fed of $\mathrm{K}_{2} \mathrm{O}$. Humic acid (marketed locally by International Company to Commerce and Investment Agriculture), main characteristics are water soluble potassium humate crystals: Fulvic acid 12\%, Humic Acid $68 \%, \mathrm{~K}_{2} \mathrm{O} 13$ $15 \%$, pH 7-10, its water Solubility $\geq 98 \%$ soluble and Moisture content is in the range $5-10 \%$. The amount of H.A. applied was $5 \mathrm{Kg} /$ fed. Effective microorganisms (EM) were available at a dormant state and required to activation before application. Activation involved addition of 20 liter of water and $1.5 \mathrm{~kg}$ of molasses to 4 liter of the dormant EM. These ingredients were mixed together and stored at minimal temperature fluctuations. This quantity was added at volume around 12 liters / tree/year which is divided in three doses / year at the rate of 4 liter/tree in dose.

\section{Soil analysis}

Soil samples were collected $(0-30 \mathrm{~cm})$ from olive field at random before the experiment, air-dried, ground, crushed, passed through a $2 \mathrm{~mm}$ sieve and stored for the determination of the physical and chemical characteristics of the soil as follows; E.C was measured in $1: 1$ soil-water extract, the $\mathrm{pH}$ was measured in 1:2.5 soil-water suspensions (Page et al. 1982), $\mathrm{CaCO}_{3}$ was measured by calcimeter (Alison and Moodle, 1965). The particles size distribution was measured by the hydrometer method according FAO (1970), the O.M. was determined according to the method of Walkley- Black (Black, 1965), total $\mathrm{N}$ was determined as described by Bremner and Mulvaney (1982), available K was determines as described by Olsen et al (1954) and K measured by flame photometer (Black, 1965) and available $\mathrm{P}$ was measured colorimetrically (Olsen and Watanab 1965), the amounts of available Fe, $\mathrm{Zn}$ and $\mathrm{Cu}$ were determined by extracting with DTPA solution according to Lindsay and Norverll (1978). Soil-moisture constants were determined on mass basis by a pressure extractor apparatus, and soil bulk density values were determined in undisturbed soil samples using the core method (Blacke and Hartge, 1986). Soil samples collected and preserved in an ice-box after harvest immediately analyzed for the biological parameters. Soil respiration was determined the evolved carbon dioxide method (Kaloosh, 1978 and Anderson, 1982). In addition, the activities of two enzymes were assayed: urease Phosphatase activity was determined according to the method described by Tabatabia (1994).

\section{Plant analysis}

Olive fruits were randomly collected from each tree for measurement of fruit weight (g), fruit diameter $(\mathrm{cm})$, and number of fruits per shoot. Productivity of olive tree in $\mathrm{kg} /$ tree was calculated to determine fruit olive yield. The oil content was determined by extracting the oil from the dried -fruits $\left(105 \mathrm{C}^{\circ}\right.$ for $\left.72 \mathrm{hr}\right)$ by Soxhelt fat extraction apparatus using petroleum ether (Woodman, 1941) according to the methods of A.O.A.C. (1990). Chlorophyll index was measured in fresh leaves using Chlorophyll meter Spad 502 according to Wood et al. (1992). Leaf water potential (bar) was measured with a portable pressure chamber apparatus (Scholander et al., 1965). Free proline content was determined according to Bates et al. (1973). In plant leaves; $\mathrm{N}$ was measured by Micro-Kjeldahl method (Jackson, 1973), P was determined colorimetrically (Chapman and Pratt, 1961) and K was measured by Flame Photometer (Jackson, 1973).

TABLE 1. The main physical and chemical characteristics of experimental soil

\begin{tabular}{|c|c|c|c|}
\hline \multicolumn{2}{|l|}{ Soil parameter } & \multicolumn{2}{|c|}{ Soil parameter } \\
\hline $\begin{array}{l}\text { Particle size distribution } \\
\text { Sand \% } \\
\text { Silt } \% \\
\text { Clay } \% \\
\text { Soil texture } \\
\text { F.C. \% } \\
\text { P.W.P. } \% \\
\text { Bulk density } \mathrm{Mg} / \mathrm{m}^{3}\end{array}$ & $\begin{array}{c}79.5 \\
13.4 \\
7.1 \\
\text { Loamy sand } \\
24.1 \\
10.27 \\
1.1\end{array}$ & $\begin{array}{cc}\mathrm{pH} \\
\mathrm{EC} \mathrm{dS} / \mathrm{m} \\
\mathrm{CaCO} 3, \% \\
\text { O.M } \quad(\%) \\
\text { T.N } \quad(\%) \\
\text { Available P } & \mathrm{mg} / \mathrm{kg} \\
\text { Available } \mathrm{K} & \mathrm{mg} / \mathrm{kg} \\
\text { DTPA-Fe } & \mathrm{mg} / \mathrm{kg} \\
\text { DTPA-Cu } & \mathrm{mg} / \mathrm{kg} \\
\text { DTPA-Zn } & \mathrm{mg} / \mathrm{kg}\end{array}$ & $\begin{array}{c}8.3 \\
1.6 \\
28.5 \\
0.60 \\
0.013 \\
7.8 \\
200 \\
5 \\
1.9 \\
2.9\end{array}$ \\
\hline
\end{tabular}




\section{Statistical analysis}

The obtained data were subjected to analysis of variance as outlined by SAS program (SAS Institute, 1988). Means for the different factors were compared according to the Fisher's Least Significant Differences at 0.05 level of probability.

\section{Results And Discussion}

\section{Fruit characters}

Fruit weight

Table 2 showed a significant increase in fruit weight of Picual variety due to treatments by $75 \%$ or $50 \%$ NPK +EM under FIW. Aggizi and Mission recorded a significant increase in fruit weight with all treatments. Koronieki fruit weight was affected significantly only by FIW with treatments of $75 \%$ NPK +EM. Under HIW regime, fruit weight of Picual, Aggizi and Mission varieties were significantly increased due to all treatments compared with the control (Table 2 ). No significant differences in fruit weight of Koronieki due to the different treatments were found (Table 2). It is also clear that there were significant increases in fruit weight of the four olive varieties due to $75 \%$ NPK + EM treatment grown under FIW while under HIW there were significant increases only at $50 \% \mathrm{NPK}+\mathrm{EM}$ treatment for picual, and Mission while for Aggizi it was at $100 \%$ NPK. The highest fruit weight was recorded for Aggizi variety followed by Picual then Mission and the lowest was that of Koronieki as a result $75 \%$ NPK + EM treatment grown under FIW. The same trend was found for these varieties when grown under HIW soil. These results agree with those reported by Hagagg et al. (2013a) showed that Aggizi olive tree, received one dose of humic acid (150 cm3), as soil application, and grown under drippers at full bloom stage and foliar sprayed with humic acid $(0.5 \%)$, produced the highest fruit weight. Using organic manure, Fayed (2010a) noted that Chicken manure gave the highest fruit weight relative to the control.

\section{Fruit diameter}

Table 2 showed that diameter of fruit of Picual variety significantly increased as a result of 100 , 75 and $50 \%$ NPK under FIW. Also, Aggizi fruit diameter was significantly increased by all treatments compared with control. Fruit diameter of Mission variety was remarkably augmented due to all treatments. Koronieki showed higher fruit diameter as a result of $75 \%$ NPK with EM or HA than $100 \%$ NPK, $50 \%$ NPK with EM or HA under FIW. The HIW induced a significant increase in fruit diameter of Picual, Aggizi and Mission varieties due to all treatments as compared with the control. Moreover, fruit diameter Koronieki olive variety significantly increased as a result of treatment by $100 \%$ NPK as well as $75 \%$ NPK + HA than $75 \%$ $\mathrm{NPK}+\mathrm{EM}$ and $50 \% \mathrm{NPK}+\mathrm{HA}$. These results are in agreement with those found by Osman and Abd El-Rhman (2010) who noted that poultry manure + azotobacter and poultry manure + azospirillum produced the highest fruit length.

\section{Number of fruits}

As shown in Table 2, under FIW, a significant increase in number of fruits of Picual variety with $75 \%$ NPK +HA while Aggizi showed no significant differences between treatments, but mission showed a significant promotion in number of fruits due to 100 $\%$ NPK. Koronieki showed a significant increase in number of fruits as a result all treatments. It is clear that under HIW, a significant increase in number of fruits of Picual due to treatments by $100 \%$ NPK, $75 \%$ NPK with EM or HA was found. Moreover, number of fruits of Aggizi significantly increased by $50 \%$ NPK + EM treatment, while mission variety showed no significant response, while Koronieki showed a significant increase in fruit number due to all treatments. These results agree with those found by Osman and Abd El-Rhman (2010) who noted that poultry manure + azotobacter and poultry manure + azospirillum gave the highest number of fruit/ shoot.

\section{Fruit yield}

Fig. (1a) showed a significant increase in fruit yield of Picual, Mission and Aggizi varieties due to all treatments grown under FIW. It is also clear that fruit yield of Koronieki variety has positively responded induced by $100 \%$ NPK, $75 \%$ NPK with EM or HA, and $50 \%$ NPK with EM or HA, while Fig. (1b) olive tree grown under HIW indicated that the fruit yield of Picual significantly promoted due to treatments by 100 $\%$ NPK, 75 \% NPK with EM or HA, while Aggizi recorded a significant increase of fruit yield as a result of treatments by $100 \%$ NPK, $75 \%$ NPK with EM or HA under HIW. Mission olive was significantly affected by all treatments compared with the control. The highest fruit yield was that of Koronieki followed by Mission then Picual and the lowest was that of Aggizi due to $100 \%$ NPK treatment and grown under FIW or HIW. The obtained results agree with those obtained by Higa (1995) it has been reported that EM can significantly enhance the yield and quality of crops. Hagagg et al. (2013b) found that Picual and Aggizi olive trees received humic acid as soil application at $150 \mathrm{~cm}^{3} /$ tree produced the

Egypt. J. Soil. Sci. 59, No. 1 (2019) 
TABLE 2. Fruits characters of varieties as influenced by water regime and treatments

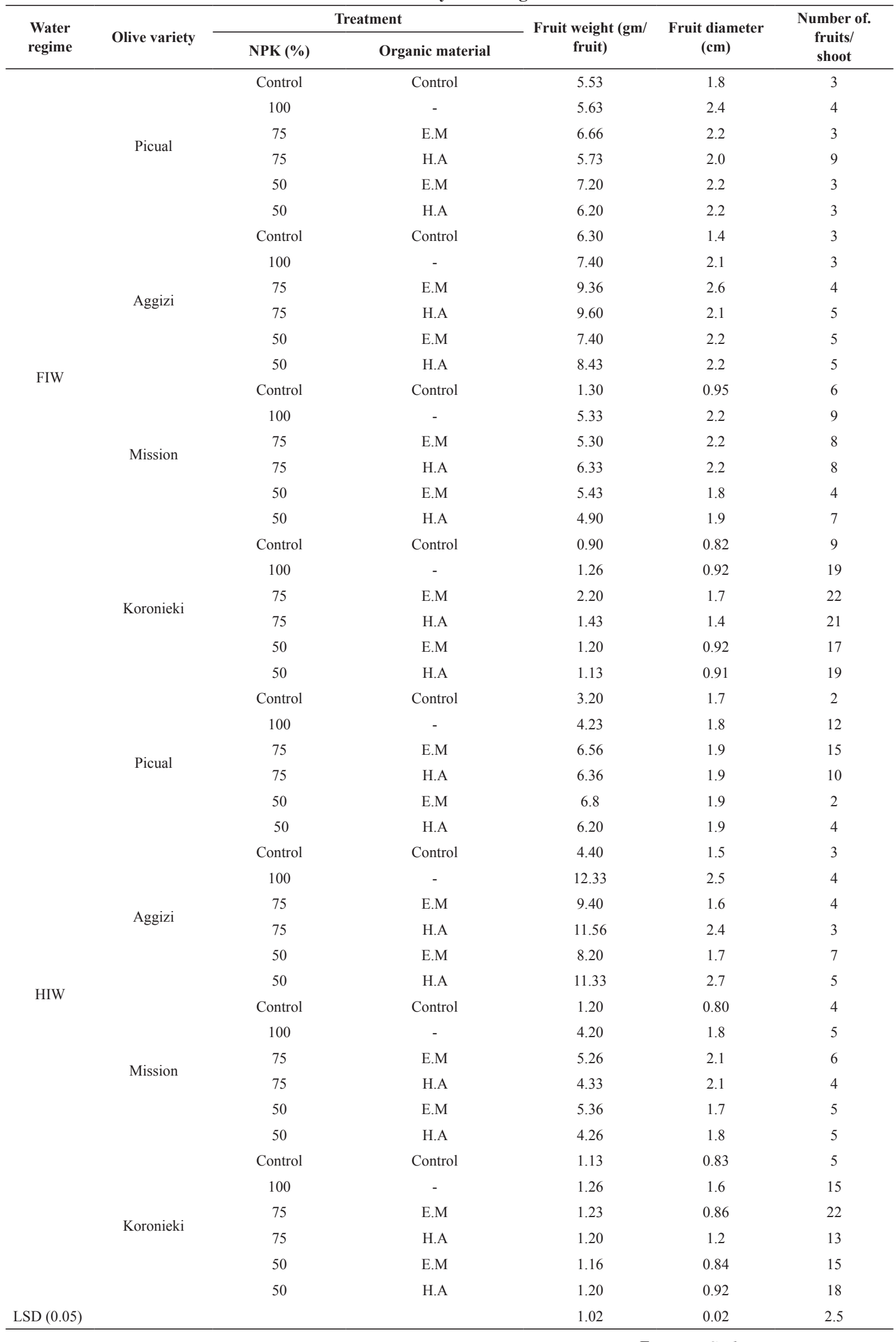


highest yield. Fayed (2010a) noted that olive yield was significantly increased as affected by organic manures applications during two growth seasons. Also, Fayed (2010b) recorded that soil application of manure tea with yeast +humic acid to Roghiani olives had better effect on fruit yield. It has been also reported that humic substances have beneficial effects on yield (Chen and Avaid, 1990).

There were significant increases in the fruit yields of the four olive varieties grown under FIW as a result of treatment by $100 \%$ NPK, 75 $\% \mathrm{NPK}+\mathrm{EM}, 75 \% \mathrm{NPK}+\mathrm{HA}, 50 \% \mathrm{NPK}+\mathrm{EM}$, or $50 \% \mathrm{NPK}+\mathrm{HA}$. The values of relative increase are shown in Table 3. It is clear that Mission olive variety had the highest values of relative fruit yield and Koronieli had the lowest values grown under either FIW or HIW regime. With respect to values of relative increase the four olive varieties can be arranged in the order: Mission $>$ Picual $>$ Aggizi > Koronieki.

\section{Fruit oil content}

Fig. (2a) showed that under FIW regime, there was a significant increase in the oil content in fruit of Picual and Mission varieties as a result of applying all treatments. Oil content in fruit of Aggizi significantly increased due to treatments by $100 \%$ NPK, $75 \%$ NPK with EM or HA. A significant increase of oil in fruit of Koronieki

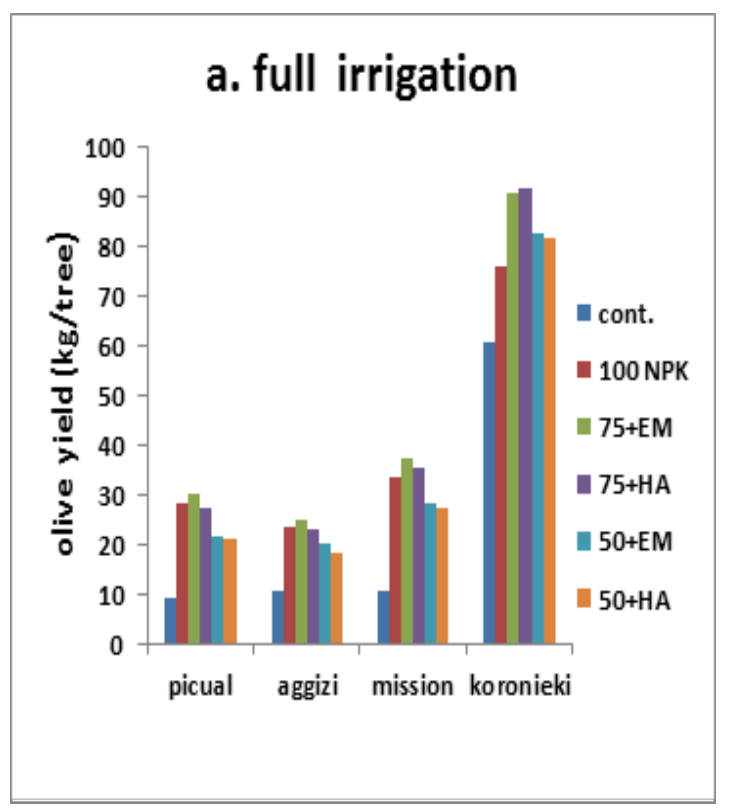

as a result of all treatments expect $50 \%$ NPK + HA. Under HIW regime, that oil content of Picual significantly increased as a result of all treatments as compared to the control. While, there was no significant effect on oil content of Aggizi Fig. (2b). However, oil content of Mission significantly increased due to all treatments. The oil content of Koronieki was significantly affected by treatments $100 \%$ NPK, $75 \%$ NPK with EM or HA treatments. It is clear from Fig. (2) that there was significant increases in the oil contents of the four varieties grown under FIW and HIW as a result of treatment by $100 \%$ NPK, $75 \%$ NPK with EM or HA and $50 \% \mathrm{NPK}+\mathrm{EM}$. The oil content was the highest in fruits of Koronieki followed by Picual then Mission and the lowest was in Aggizi. These results are in agreement with those obtained by El-Sayed (2013) showed that $10 \mathrm{~g}$ yeast /tree $+60 \mathrm{~g}$ humic acid/ tree produced the high fruit oil percent. Nikbakht et al. (2011) showed that HA decreased oil content of olive. Regarding to oil quality, it is indicated that oils unsaturation degree was improved by HA. Although HA had no positive effect on yield and oil content, it was an enhancement of nutritional value of the oils. Hagagg et al. (2013 a) claimed that Aggizi olive tree received humic acid at $150 \mathrm{~cm}^{3} /$ tree produced the highest fruit oil. In addition, Fayed (2010a) found that oil productivity was significantly increased as affected by organic manure applications.

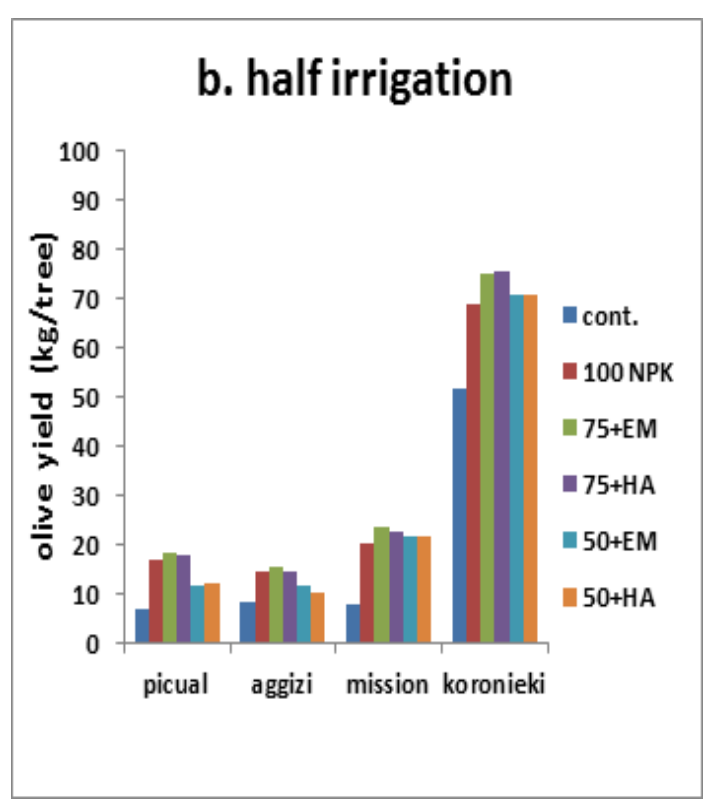

Fig. 1. The olive yield of the four olive varieties as influenced by different treatments in full and half irrigation water regime

Egypt. J. Soil. Sci. 59, No. 1 (2019) 


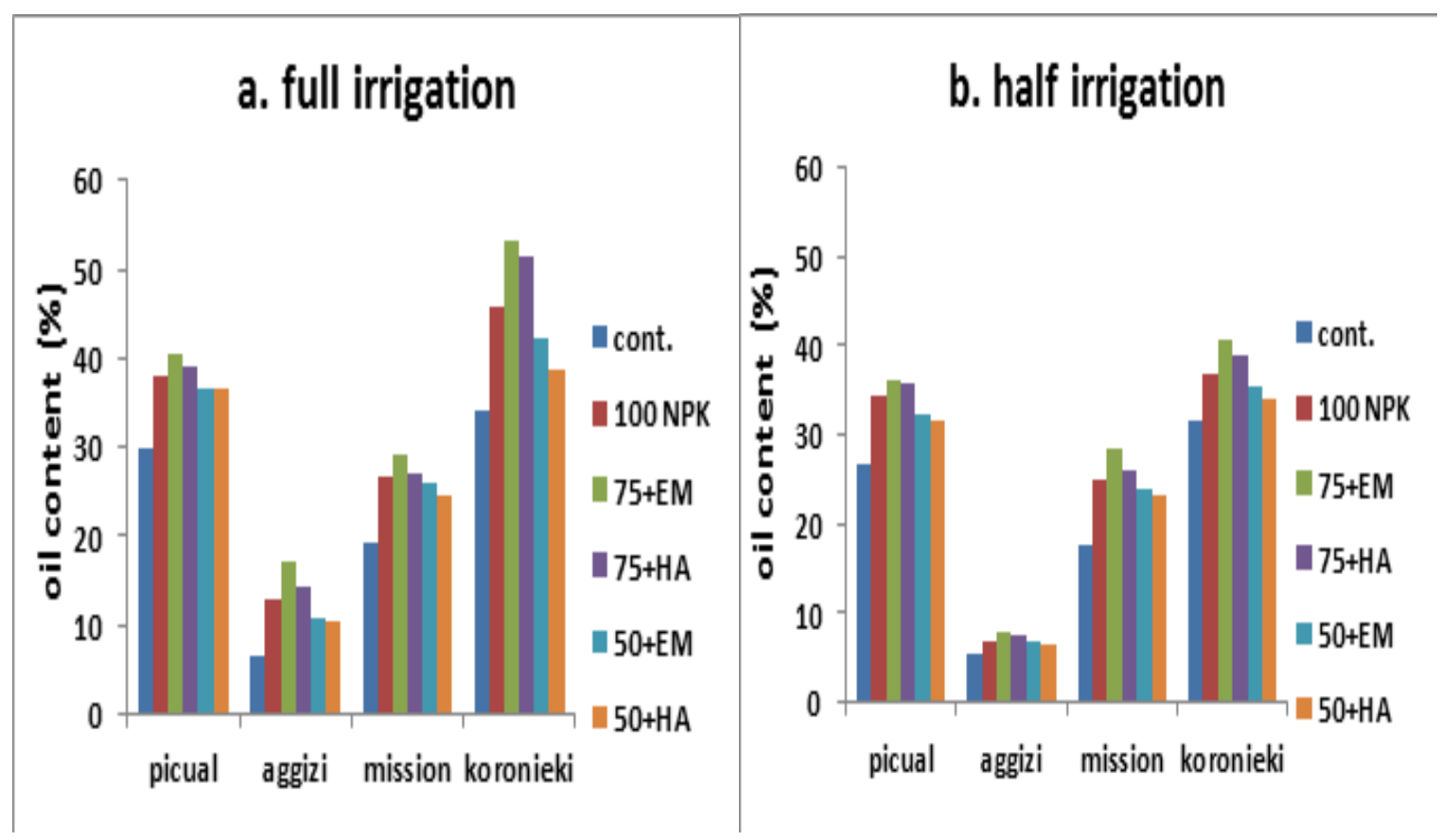

Fig. 2. The olive oil content of the four olive varieties as influenced by different treatments in full and half irrigation water regime

There was a significant increase in the oil content in fruits of the four olive varieties grown under either FIW or HIW regime as a result of NPK, EM and HA treatments (Table 4). The values of relative increase of oil content in fruits were the highest due to $75 \% \mathrm{NPK}+\mathrm{EM}$ treatment for the four olive varieties under FIW or HIW regime. It is clear that for plants grown under FIW the highest value of relative increase of oil percentage was that of Aggizi olive variety while those of Picual, Mission and Koronieki were the lowest and shown approximately close values with all treatments and the lowest were due to 50 $\% \mathrm{NPK}+\mathrm{HA}$. On the other hand, for olive plants grown under HIW, the values of relative increase of oil content in fruits were low and approximately close and less than value of $50 \%$ except those of Aggizi ( $>50 \%$ ) as a result of $75 \%$ NPK +EM treatment.

\section{Biochemical Constituents \\ Chlorophyll content}

Table 5 showed significant increase of chlorophyll index in leaves of Picual as a result of the treatments under FIW regime. While, Aggizi variety treated by $75 \%$ NPK +EM showed significant increase of chlorophyll index as compared with other treatments. Chlorophyll index in leaves of Mission significantly increased by $75 \%$ NPK +EM treatments as compared with the control. koronieki treated by
$75 \%$ NPK with EM or HA showed significant increase in chlorophyll index in plant leaves as compared with other treatments. Under HIW, chlorophyll index in leaves of Picual, Aggizi and Mission had significantly increased in olive leaves with all treatments, and $75 \%$ and 50\% NPK +EM treatment showed significant higher values. Koronieki revealed significant increase in chlorophyll index due to all treatments as compared with the control (Table 5). In general, the obtained data showed significant promotion in the levels of chlorophyll index in leaves of the four olive varieties grown under FIW or HIW regime as a result of $100 \%$ NPK treatment relative to the control. The values of chlorophyll index in leaves were almost higher in leaves of Koronieki than in those of Picual, Aggizi or Mission grown under FIW or HIW. These results agree with those obtained by Osman and Abd ElRhman (2010) who noted that poultry manure + azotobacter and poultry manure + azospirillum stimulated the highest total chlorophyll. Khamis et al. (2010) found that Manzanillo leaves were the richest in chlorophyll while the reverse was true in Koronieki leaves. Osman (2010) noted that Manzanillo leaves were the highest in chlorophyll and the lowest in caratenoids. Abbas et al. (2013) reported that humic acid (12\%) significantly increased the chlorophyll content in leaves of olive cultivars. 


\section{Proline}

Under FIW, there was significantly decrease in proline content in leaves of Mission variety as a result of treatment by $100 \%$ NPK, $75 \%$ NPK with EM or HA and by $50 \%$ NPK + EM, and in leaves of Koronieki variety treated by $75 \%$ NPK $+\mathrm{HA}$ (Table 5). Under HIW, the proline content in leaves of Picual and Aggizi varieties decreased as a result of all treatments compared with the control. Mission and Koronieki contained significantly lower proline in their leaves due to $75 \%$ NPK with EM or HA as compared with all treatments. Table 6 indicated that there is a significant decrease in proline content in leaves of the four olive varieties grown under FIW due to $100 \%$ NPK treatment in comparison with to the control plant.

\section{Leaf water potential (LWP)}

Table 5 showed that olive tree grown under FIW are characterized by significant decrease in LWP of Picual and Koronieki due to the treatments as compared with the control, while LWP in Aggizi and Mission significantly decreased as a result of treatments by $100 \%$ NPK, $75 \%$ NPK with EM or HA as compared with the control. Olive grown under HIW is characterized by low levels of LWP in leaves of Picual, Aggizi and Mission varieties as a result of treatment by $100 \%$ NPK, $75 \%$ NPK with EM or HA and by $50 \%$ NPK + HA as compared to the control.

\section{Macronutrients in olive leaves}

Nitrogen

Fig. (3a) showed significant increase in the concentration of $\mathrm{N}$ in leaves of the four olive varieties grown under FIW as a result of all treatments and also in which are grown under HIW(Fig. 3b), except 50\% NPK + HA treatment which showed no significant effect with Mission, and $50 \%$ NPK +EM which showed no significant effect with Koronieki. Fig. (3a) showed significant increase of $\mathrm{N}$ in leaves of the four olive varieties grown under FIW as a result of $100 \%$ NPK treatment.

\section{Phosphorus}

Under FIW regime (Fig. 4a) significant increases of P content in leaves of the four olive varieties were found due to $75 \%$ NPK with HA or EM. Also, HIW regime showed that $P$ in leaves of Picual variety significantly increased as a result of all treatments except $50 \% \mathrm{NPK}+\mathrm{EM}$. In leaves of Aggizit and mission, P significantly increased due to all treatments compared with the control. The P content in leaves of Koronieki significantly increased due to all treatments except $50 \%$ NPK +HA (Fig. 4b).

\section{Potassium}

In the case of olive grown under FIW, the treatment $75 \%$ NPK +EM had significantly increased $\mathrm{K}$ content in leaves than the other treatments followed by $75 \%$ NPK +HA (Fig. 5a). In the case of HIW regime, $\mathrm{K}$ content in leaves had significantly increased due to treatment by $75 \%$ NPK +EM followed by $75 \%$ NPK +HA(Fig. 5b). The obtained data generally showed significant increases in the concentrations of $\mathrm{K}$ in leaves of all olive varieties grown under FIW or HIW due to $100 \%$ NPK treatment (Fig. 5).These results are in harmony with those obtained by Osman and Abd El-Rhman (2010), and, Hegazy et al. (2007) who reported that organic and bio-fertilization significantly increased $\mathrm{N}$ and $\mathrm{K}$ contents, while $\mathrm{P}$ showed no significant difference with Picual olive due to $100 \%$ organic fertilization. El-Sayed (2013) found that $10 \mathrm{~g}$ yeast/tree $+60 \mathrm{~g} \mathrm{H.A} /$ tree enhanced $\mathrm{K}$ content in plant leaves, this was also found by Fayed (2010b).

\section{Macronutrients in soil \\ Total N}

Total N content in soil (Fig. 6a) significantly increased as a result of application of all treatments and varieties grown under FIW as compared with the control. Picual, Aggizi, and Mission under HIW contained also high T.N due to all treatments as compared with the control (Fig. 6b). Total $\mathrm{N}$ in Koronieki soil was high due to $75 \%$ NPK +EM treatment, whether under FIW or HIW regime.

\section{Available phosphorus}

Fig. (7a) showed that the amount of available P significantly increased in Picual and Koronieki's in soils as a result of all treatments as compared to the control. Aggizi and Mission soils contained high amounts of available $\mathrm{P}$ due to $100 \% \mathrm{NPK}, 75 \%$ NPK with EM or HA and $50 \%$ NPK + HA under FIW. Also, under HIW, available P was significantly higher in Picual, Mission and Koronieki soils due to all treatments than the control (Fig. 7b). Treatment with EM increased available $\mathrm{P}$ in soil as compared to the control. Soil microorganisms play significant role in mobilizing $\mathrm{P}$ by lowering $\mathrm{pH}$ of the rhizosphere soil, producing chelating substances lead to solubilization of phosphates (Subba-Rao., 1991).

\section{Available potassium}

Fig. 8 showed significant increase in the amount of available $\mathrm{K}$ in soil under FIW or HIW, and treated with $75 \%$ NPK +EM followed by $75 \%$ NPK + HA. These results agree with those obtained by Higa. (1995). Olk and Cassman (1995) reported that HA added to vermiculitic soils reduced $\mathrm{K}$ fixation and increased extractable $\mathrm{K}$ and highly labile $\mathrm{K}$, as well as plant $\mathrm{K}$ uptake. These results agree with those found by Cóndor Golec (2007) and Xiloyannis et al. (2000) who reported that nutrient uptake from soil in irrigated olive trees was relatively steady during the different growth stages of the year. 
TABLE 3. Relative variation (\%) of olive fruit as a result of treatments and irrigation water regime

\begin{tabular}{|ccccc|}
\hline \multirow{2}{*}{ Olive variety } & Treatment & \multicolumn{2}{c|}{ Irrigation regime } \\
\cline { 2 - 5 } Picual & NPK (\%) & Organic material & FIW & HIW \\
& 100 & - & 206.12 & 148.66 \\
& 75 & E.M & 226.32 & 173.88 \\
& 75 & H.A & 196.35 & 163.73 \\
& 50 & E.M & 135.12 & 71.49 \\
& 50 & H.A & 125.99 & 80.75 \\
& 100 & - & 122.64 & 81.23 \\
Aggizi & 75 & E.M & 136.13 & 92.59 \\
& 75 & H.A & 118.21 & 80.25 \\
& 50 & E.M & 91.13 & 43.33 \\
& 50 & H.A & 73.87 & 27.16 \\
Koronieki & 100 & - & 215.63 & 155.99 \\
& 75 & E.M & 253.79 & 196.34 \\
& 75 & H.A & 236.46 & 181.97 \\
& 50 & E.M & 169.89 & 171.12 \\
& 50 & H.A & 158.52 & 169.86 \\
& 50 & - & 25.26 & 33.45 \\
& 100 & E.M & 49.67 & 45.72 \\
& 75 & H.A & 51.54 & 46.89 \\
& 50 & E.M & 36.52 & 37.02 \\
& 50 & 34.77 & 37.02 \\
\hline
\end{tabular}

TABLE 4. Relative variation (\%) of olive oil as a result of treatments and irrigation water regime

\begin{tabular}{|c|c|c|c|c|}
\hline \multirow{2}{*}{ Olive variety } & \multicolumn{2}{|c|}{ Treatment } & \multicolumn{2}{|c|}{ Irrigation regime } \\
\hline & NPK (\%) & Organic material & FIW & HIW \\
\hline \multirow{5}{*}{ Picual } & 100 & - & 28.28 & 27.99 \\
\hline & 75 & E.M & 36.70 & 34.70 \\
\hline & 75 & H.A & 31.31 & 33.21 \\
\hline & 50 & E.M & 23.23 & 20.52 \\
\hline & 50 & H.A & 22.90 & 18.28 \\
\hline \multirow{5}{*}{ Aggizi } & 100 & - & 95.45 & 28.30 \\
\hline & 75 & E.M & 160.61 & 47.17 \\
\hline & 75 & H.A & 116.67 & 41.51 \\
\hline & 50 & E.M & 65.15 & 28.30 \\
\hline & 50 & H.A & 59.09 & 22.64 \\
\hline \multirow{5}{*}{ Mission } & 100 & - & 37.11 & 41.24 \\
\hline & 75 & E.M & 50.52 & 61.02 \\
\hline & 75 & H.A & 39.69 & 48.02 \\
\hline & 50 & E.M & 34.54 & 35.59 \\
\hline & 50 & H.A & 27.32 & 31.07 \\
\hline \multirow{5}{*}{ Koronieki } & 100 & - & 34.71 & 15.77 \\
\hline & 75 & E.M & 56.47 & 28.71 \\
\hline & 75 & H.A & 51.18 & 22.71 \\
\hline & 50 & E.M & 23.82 & 11.36 \\
\hline & 50 & H.A & 14.12 & 7.89 \\
\hline
\end{tabular}


TABLE 5. Chlorophyll, proline, and LWP in

\begin{tabular}{|c|c|c|c|c|c|c|}
\hline \multirow{2}{*}{$\begin{array}{l}\text { Water } \\
\text { regime }\end{array}$} & \multirow{2}{*}{ Olive variety } & \multicolumn{2}{|c|}{ Treatment } & \multirow{2}{*}{$\begin{array}{l}\text { Chlorophyll } \\
\text { index }\end{array}$} & \multirow{2}{*}{$\begin{array}{c}\text { Proline } \\
(\mu \mathrm{g} / \mathrm{g})\end{array}$} & \multirow{2}{*}{$\begin{array}{c}\text { Leaf water } \\
\text { potential } \\
\text { (Bar) }\end{array}$} \\
\hline & & NPK (\%) & Organic material & & & \\
\hline \multirow{22}{*}{ FIW } & \multirow{6}{*}{ Picual } & Control & Control & 50.73 & 52.87 & -32.20 \\
\hline & & 100 & - & 67.93 & 21.05 & -23.53 \\
\hline & & 75 & E.M & 73.13 & 19.79 & -28.20 \\
\hline & & 75 & H.A & 72.66 & 19.13 & -27.26 \\
\hline & & 50 & E.M & 81.40 & 22.76 & -30.40 \\
\hline & & 50 & H.A & 80.46 & 25.24 & -30.86 \\
\hline & \multirow{7}{*}{ Aggizi } & Control & Control & 50.72 & 45.88 & -30.66 \\
\hline & & 100 & - & 71.70 & 26.50 & -20.20 \\
\hline & & 75 & E.M & 84.25 & 26.69 & -15.26 \\
\hline & & 75 & H.A & 78.40 & 26.35 & $-10 . .46$ \\
\hline & & 50 & E.M & 75.00 & 26.86 & -30.20 \\
\hline & & 50 & H.A & 73.33 & 27.07 & -28.13 \\
\hline & & Control & Control & 50.53 & 29.54 & -30.40 \\
\hline & \multirow{5}{*}{ Mission } & 100 & - & 72.16 & 21.82 & -24.26 \\
\hline & & 75 & E.M & 85.38 & 11.38 & -12.20 \\
\hline & & 75 & H.A & 74.40 & 11.74 & -14.73 \\
\hline & & 50 & E.M & 78.23 & 20.58 & -30.40 \\
\hline & & 50 & H.A & 82.23 & 25.39 & -27.20 \\
\hline & \multirow{8}{*}{ Koronieki } & Control & Control & 56.43 & 24.27 & -26.33 \\
\hline & & 100 & - & 83.30 & 20.15 & -13.35 \\
\hline & & 75 & E.M & 89.00 & 19.17 & -11.40 \\
\hline & & 75 & H.A & 88.15 & 10.39 & -10.53 \\
\hline \multirow{27}{*}{ HIW } & & 50 & E.M & 84.73 & 21.50 & -16.40 \\
\hline & & 50 & H.A & 83.46 & 20.26 & -15.26 \\
\hline & & Control & Control & 48.80 & 55.66 & -33.00 \\
\hline & & 100 & - & 65.36 & 26.73 & -15.33 \\
\hline & \multirow{3}{*}{ Picual } & 75 & E.M & 80.60 & 21.36 & -16.46 \\
\hline & & 75 & H.A & 83.06 & 23.76 & -17.43 \\
\hline & & 50 & E.M & 71.25 & 26.91 & -28.20 \\
\hline & \multirow{8}{*}{ Aggizi } & 50 & H.A & 70.50 & 30.93 & -28.60 \\
\hline & & Control & Control & 56.43 & 42.92 & -34.53 \\
\hline & & 100 & - & 73.16 & 23.23 & -25.60 \\
\hline & & 75 & E.M & 69.30 & 25.42 & -14.26 \\
\hline & & 75 & H.A & 67.46 & 25.11 & -16.33 \\
\hline & & 50 & E.M & 84.43 & 26.23 & -27.20 \\
\hline & & 50 & H.A & 72.36 & 30.79 & -29.73 \\
\hline & & Control & Control & 45.06 & 37.66 & -30.40 \\
\hline & \multirow{4}{*}{ Mission } & 100 & - & 70.80 & 23.11 & -17.20 \\
\hline & & 75 & E.M & 85.06 & 19.65 & -15.60 \\
\hline & & 75 & H.A & 72.83 & 14.06 & -16.20 \\
\hline & & 50 & E.M & 80.30 & 27.25 & -28.33 \\
\hline & \multirow{8}{*}{ Koronieki } & 50 & H.A & 77.60 & 29.24 & -26.13 \\
\hline & & Control & Control & 52.53 & 37.23 & -28.60 \\
\hline & & 100 & - & 82.33 & 25.11 & -20.20 \\
\hline & & 75 & E.M & 85.90 & 20.54 & -19.40 \\
\hline & & 75 & H.A & 83.96 & 12.53 & -12.66 \\
\hline & & 50 & E.M & 83.85 & 27.17 & -15.20 \\
\hline & & 50 & H.A & 70.66 & 27.55 & -17.20 \\
\hline & & $\operatorname{LSD}(0.05)$ & & 9.5 & 5.8 & 3.8 \\
\hline
\end{tabular}

Egypt. J. Soil. Sci. 59, No. 1 (2019) 


\section{a. full irrigation}

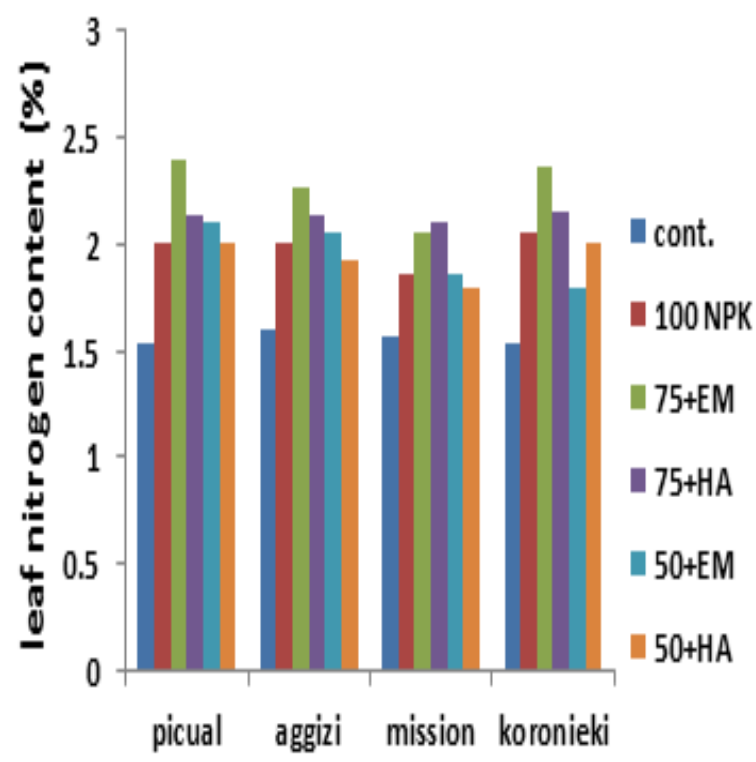

\section{b. half irrigation}

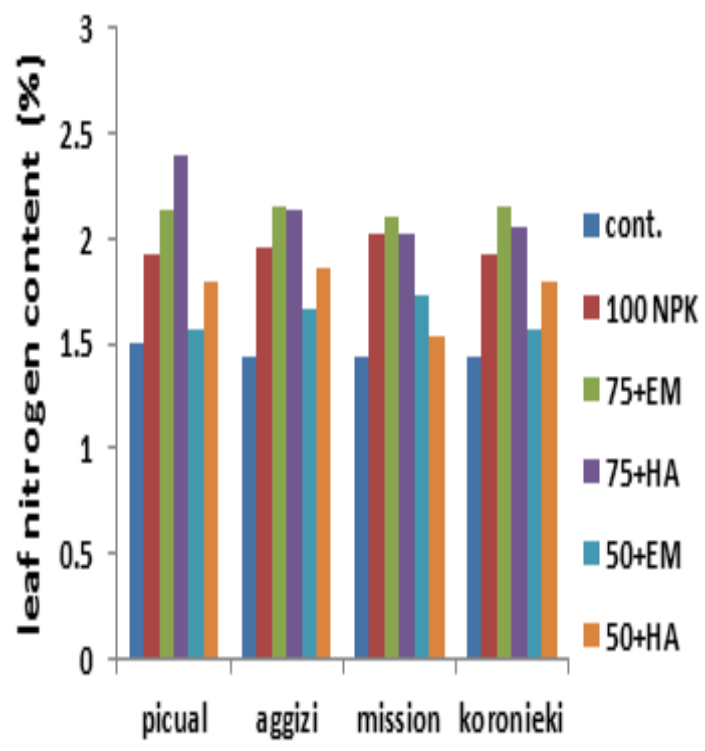

Fig. 3. The leaf nitrogen content of the four olive varieties as influenced by different treatments in full and half irrigation water regime
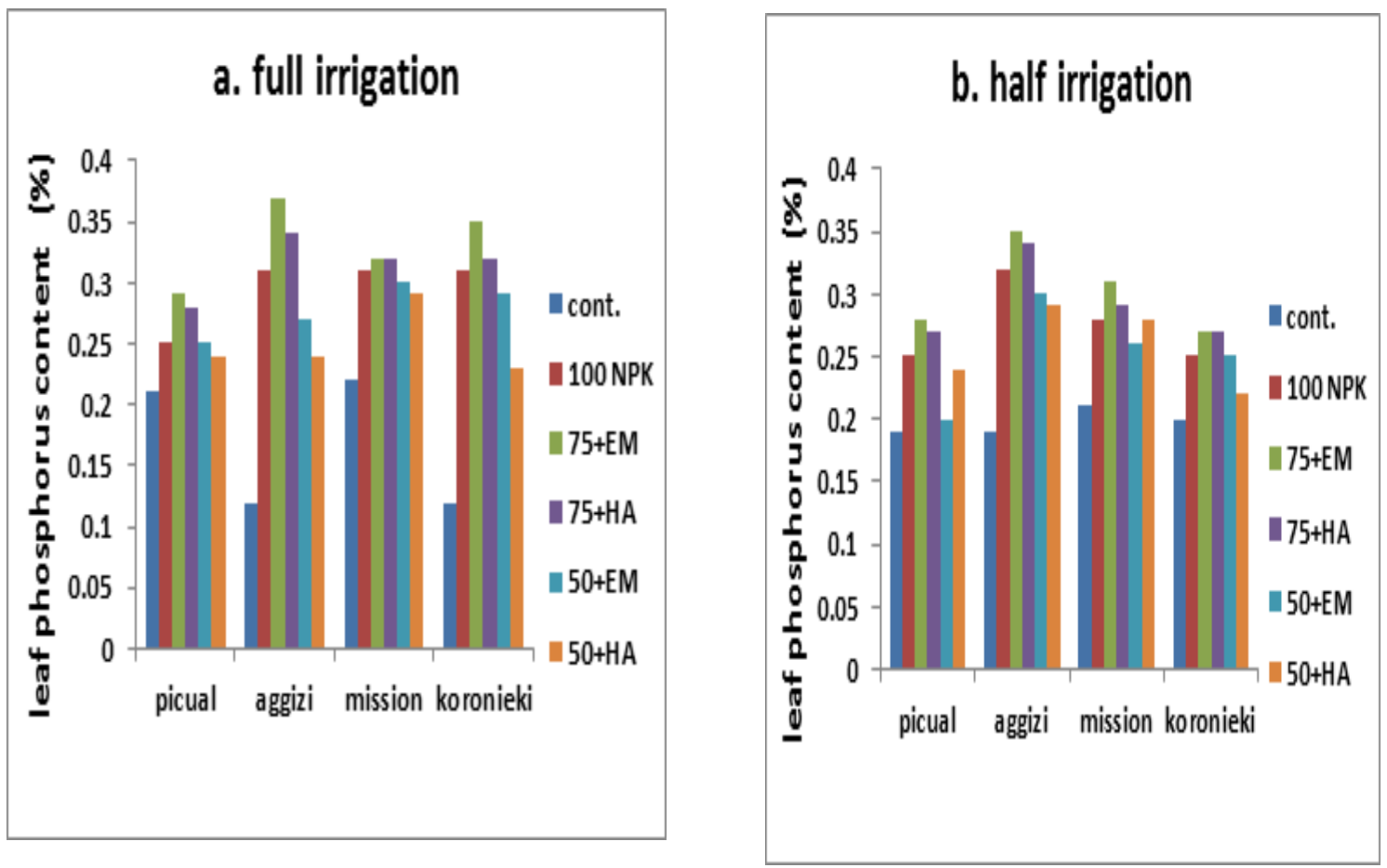

Fig. 4. The leaf phosphorus content of the four olive varieties as influenced by different treatments in full and half irrigation water regime 


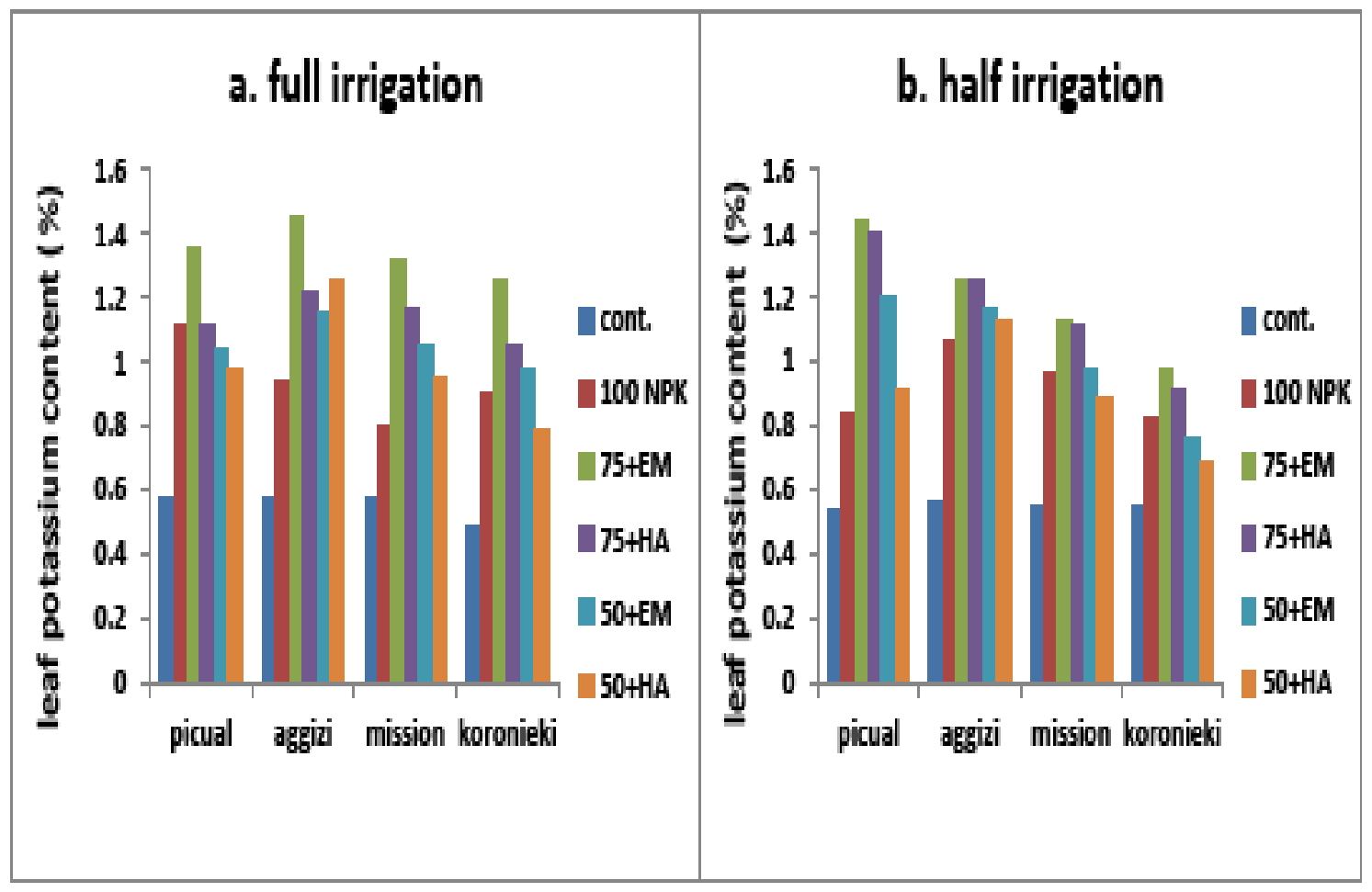

Fig 5. The leaf potassium content of the four olive varieties as influenced by different treatments in full and half irrigation water regime

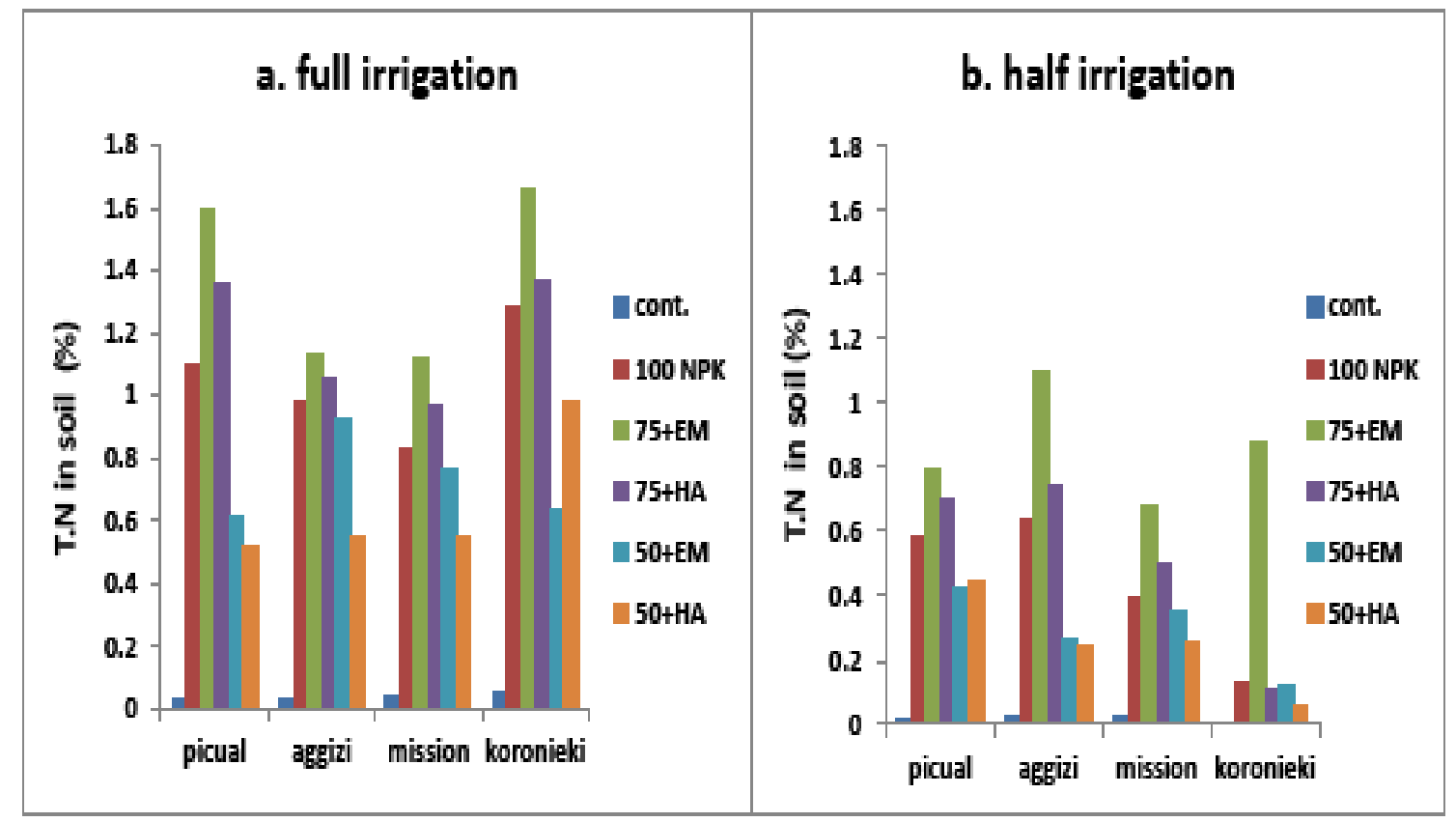

Fig 6. The total $\mathbf{N}$ content in soil of the four olive varieties as influenced by treatments in full and half irrigation water regime

Egypt. J. Soil. Sci. 59, No. 1 (2019) 

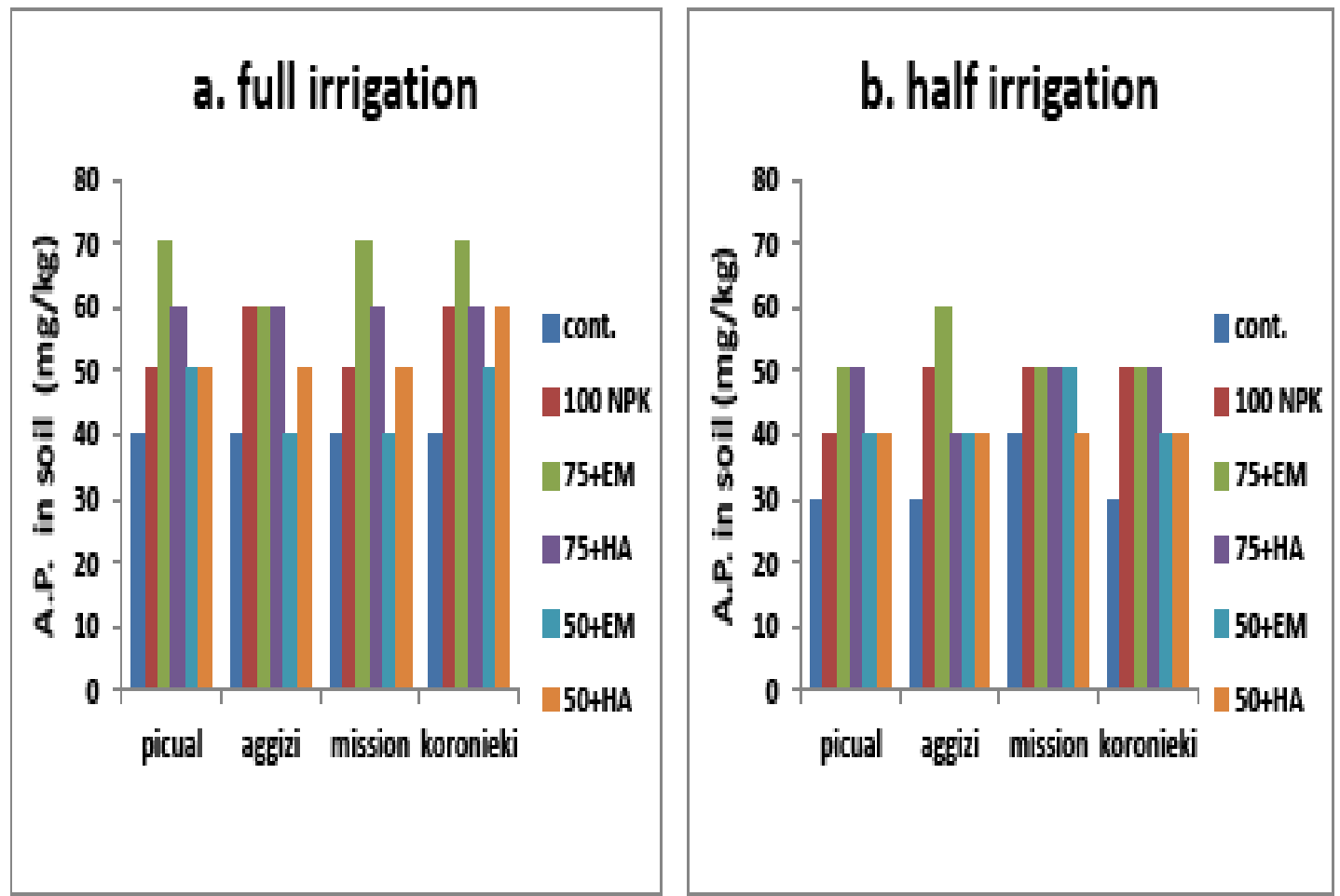

Fig 7. The amount of available $P$ in soil of the four olive varieties as influenced by different treatments in full and half irrigation water regime

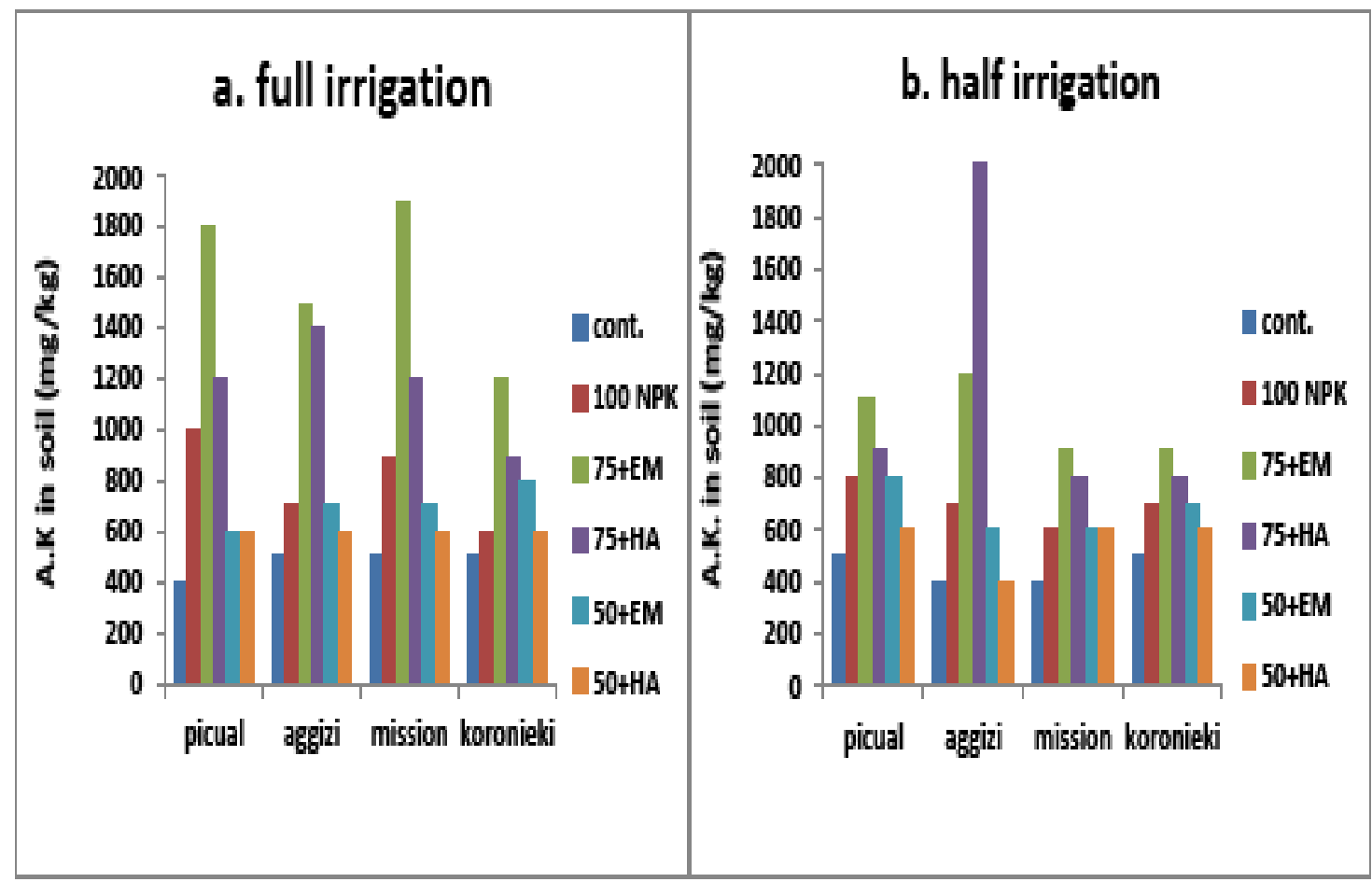

Fig. 8. The amount of available $K$ in soil of the four olive varieties as influenced by different treatments in full and half irrigation water regime 
TABLE 6. Biological parameters in soil of varieties as influenced by water regime and treatments Biochemical and Enzyme Activity

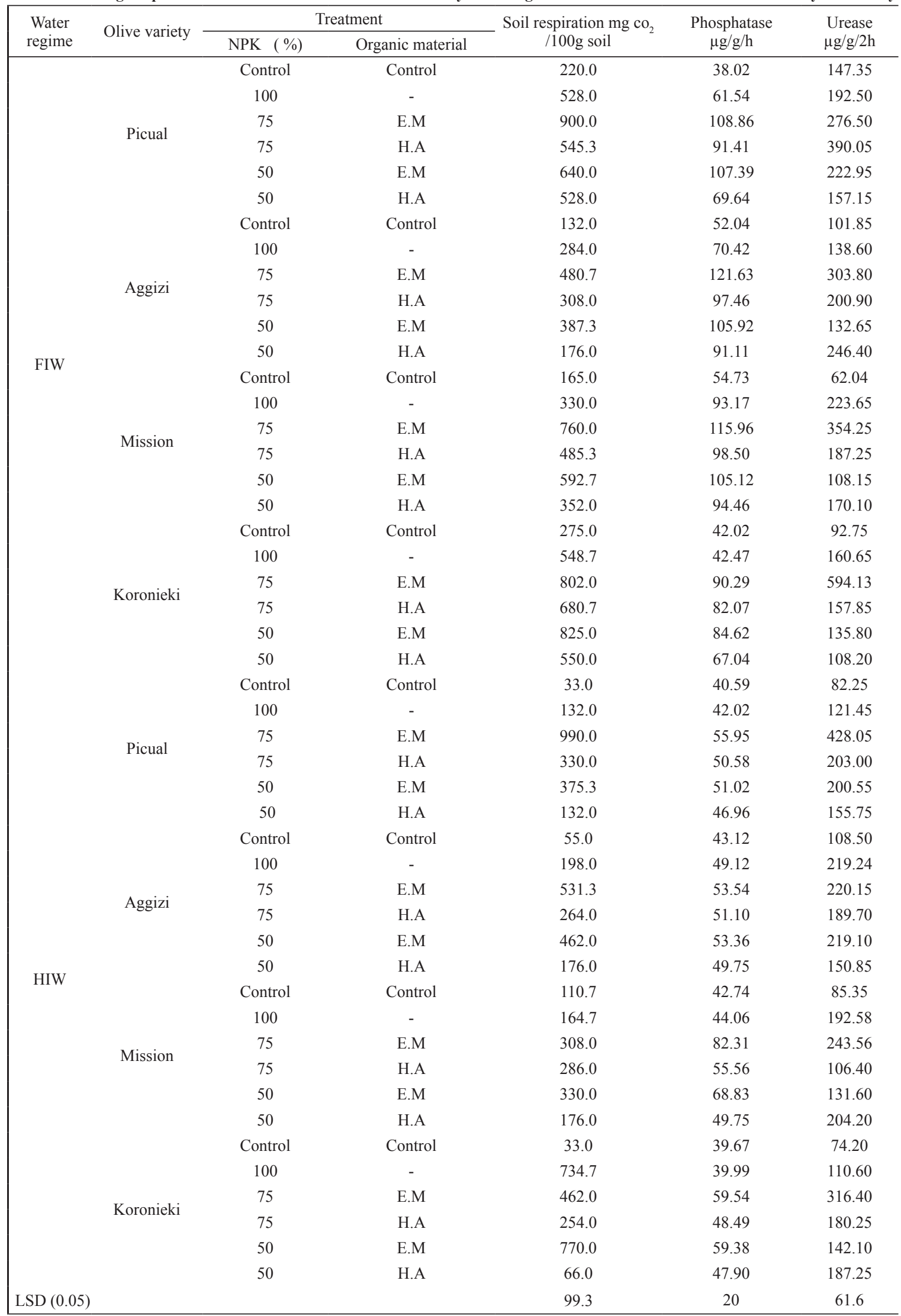

Egypt. J. Soil. Sci. 59, No. 1 (2019) 


\section{Soil respiration}

Significant increase in the rate of soil respiration has been found as a result of soil cultivation with the four olive varieties whether grown under FIW or HIW regime due to 75 and $50 \%$ NPK + EM treatment (Table 6).

\section{Phosphatase activity}

Table 6 showed significant increases in phosphatase activity in soil cultivated with the four olive varieties grown under FIW or HIW regime due to $75 \%$ NPK + EM treatment followed by 50 $\% \mathrm{NPK}+$ EM treatment.

\section{Urease activity}

Urease activity in soil cultivated with the four olive varieties significantly increased as a result of $75 \%$ NPK + EM treatment when grown under FIW or HIW regime (Table 6). These results are in agreement with obtained by Chen and Aviad (1990) and Chen et al., (2004).

\section{Conclusion}

Picual and Aggizi olive varieties grown under FIW or HIW, and treated by $75 \%$ NPK +EM or $50 \%$ NPK +EM showed significantly increased in the fruit weight. However all treatments showed significant increase in fruit weight of Mission variety. While, Koronieki variety showed no significant response to each treatments. With respect to oil content in olive fruit, the four olive varieties showed significant response to 100 $\%$ NPK, $75 \%$ NPK with EM treatment or HA treatment under FIW, while, only Picual and Mission showed higher response to these treatment when grown under HIW. Chlorophyll index was the most represented indicator for the response of each olive variety to the tested treatments. The highest significant values of chlorophyll index were obtained with olive varieties treated by $75 \%$ NPK with EM, or HA, by $50 \%$ NPK with EM or HA under FIW. On the other hand, the four olive varieties showed high significant response to most treatments under HIW. The concentration of NPK in leaves of the four olive varieties significantly increased as a result of applying the all treatments when plants are grown under FIW or HIW. Treatment by 100, 75 and $50 \%$ NPK with EM or HA significantly increased the levels of total $\mathrm{N}$, available $\mathrm{P}$ and $\mathrm{K}$ in soil under FIW or HIW regime. There was also significant increase in soil respiration as a result of all treatments. However, the levels of soil respiration were almost higher under FIW than HIW in soils cultivated with the four olive varieties, and were the highest in
Mission's soil and the lowest in Aggizi's soil under FIW regime.

It can be recommended that application of 75 $\%$ NPK of the recommended NPK to olive by Ministry of Agriculture and Land Reclamation with E.M or HA treatments are considered the best for obtaining high response of olive trees under half irrigation water regime which can save significant quantity of water of irrigation. Also, cultivating Mission or Picual olive variety in calcareous soil can tolerate drought and water shortage with the use of low rate of NPK mineral fertilizers in combination with organic or biological fertilizers under HIW regime.

\section{References}

Abbas, J. A., R. T. Balakt., A.H. Arian. 2013 Effect humic acid in some indicators of vegetative growth for palm off shoot (Phoenix dactylifera L.) irrigated with water well. Inter. J.Sci. Technol. 8 (3), 79-83.

Alison, L. E., C.D. Moodle. 1965 Carbonate. In: Methods of Soil Analysis, C.A. Black (ed.). Amer. Soc. Agron. Inc., Madison, Wisc., pp. 1379-1396.

A.O.A.C. 1990 Association of Official Agriculture Chemists, official and tentative methods of analysis. The A.O.A.C., Washington, D.C., U.S.A.

Anderson, J.P.E.1982 Soil Respiration. Methods of Soil Analysis, Part 2. Chemical and Microbiological properties. In:Page,et al.(eds.). Soil Sci. Soc. Am., Madison, Wisconsin, pp. 831-871.

Attalla, A.M., M. Abdel-Sattar, A.E. Mahrous and A.A. Abdel-Azeez. 2011 Olive trees productivity in response to supplemental irrigation under northwestern coastal conditions in Egypt. Am.Eurasian J. Agric. Environ. Sci., 11 (5), 609-615.

Bates, L.S., R.P. Waldren., I.D. Teare, 1973 Rapid determination of free proline for water-stress studies. Plant and Soil, 939, 205-207.

Black, C.A., D.D. Evans., J. L. White., L.E. Ensminger., F.E. Clark. 1965 Methods of Soil Analysis. Parts 1 and 2. Am. Soc. Agron., Inc., Madison, Wisconsin, U.S.A.

Bongi, G., A. Palliott. 1994 Olive. In: B. Schaffer and P.C. Andersen (eds.), Handbook of environmental physiology of fruit crops.

Bremner, J.M., C.S. Mulvaney. 1982 Total nitrogen. In A.L. Page (eds.). Methods of Soil Analysis, Part2. Chemical and Microbiological Properties. Agron. Monograph No. 9 (2 ${ }^{\text {nd }}$ Edition).

Egypt. J. Soil. Sci. 59, No. 1 (2019) 
Blake,G.R., K.H. Hartage. 1986 Bulk density. In Klute, A., Ed., Methods of Soil Analysis part 1- Physical and Mineralogical Methods.

Cano- Lamadrid,M., L.F. Giran, R. Pleite, F.Burlo, A. Moriana, and A.A. Carbonell-Barrachina. 2015 Quality attributes of table olives as affected by regulated deficit irrigation. L.WT-Food Sci Technol. 62, 19-26.

Chapman, H.D., P.E. Pratt. 1961 Methods of Analysis for Soil, Plant and Water. Devis. Agric. Sci. Pull Office, Calif. Univ., pp: 220 -308.

Chehab, H., B. Mechri., A. Haouari., Z. Mahjoub., M. Braham., D. Boujnah. 2014 Effect of two dripirrigtion regimes on sap flow, water potential and leaf photosynthetic activity of mature olive trees. African J. Agric. Res. 9 (31).pp: 2443-2452.

Chen Y, T . Aviad. 1990 Effects of humic substances on plant growth. In: Mac Carthy P, Clapp CE, Malcolm RL, Bloom PR. (eds.). Humic Substances in Soil and Crop Science: Selected readings. SSSA and ASA, Madison, WI, 161-186.

Chen, Y., C.E. Clapp, H. Magen. 2004 Mechanisms of plant growth stimulation by humic substances: The role of organic-iron complexes. Soil Sci. Plant Nutr, 50, 1089-1095.

Cóndor_Golec, A. F., P. G. Pérez., y. C. Lokare 2007Effective Microorganisms: Myth or reality? Microorganismos eficaces: mito o realidad? Rev. Peru. Biol. 14(2), 315- 319.

Dimitrios. B. 2006 Characteristics of the Olive Tree and Olive Fruit. AOCS Press.

Doorenbos, J., A.H. Kassam. 1986 Yield Response to Water. FAO, Irrigaton and Drainge Paper No. 33, Rome, Italy.

El-Fouly, M. M., A. A. El-Sayed, A. F. A. Fawzi., S. H. A. Shaaban. 2007 Nutritional status of oil olives grooves grown under dry farming conditions in the North Western Coast of Egypt. J. Food. Agric. Environ. 5 (1), 216 - 219.

El-Sayed. M. O. 2013 Improvement of aggizy olive trees productivity in saline calcarious soils using active dry yeast and humic acid. J. Agric. Biological Sci. 9(5), 136-144.

Evenhuis,B., P.W. De Waard. 1980 Principles and Practices in Plant Analysis. FAO.Soil Bull. 39 (1), 152-162.

\section{FAO STAT, 2010}

Egypt. J. Soil. Sci. 59, No. 1 (2019)
FAO.1970 Physical and Chemical Methods of Soil and Water Analysis.Soils Bull.No.10,FAO,Rome, Italy.

Fayed, T.A. 2010a Response of four olive cultivars to common organic manures in Libya. Am-Euras. J. Agric. Environ. Sci., 8 (3), 275-291.

Fayed, T.A. 2010b Optimizing yield, fruit quality and nutrition status of Roghiani olives growen in Libya using organic extracts. J. Hort. Sci. Ornamen. Plants, 2(2), 63-78.

Hagag. F. L., E.A.E. Genaidy., M.F.M. Shahin, N. S. Mustafa., H. S. A. Hassan. 2013b Effect of number of applications of humic acid on fruit quality and quantity of Picual olives under North Sinai condition. J. Appl. Sci. Res., 9(2), 1092-1096.

Hagag. F. L., M.F.M. Shahin, Maha Afifi, Mahdy H.A., N.S. Mustafa. 2013a Optimizing fruit quality and quantity of "Aggizi" olive trees cultured in North Sinai by using some organic extracts. Middle East J. Appl. Sci., 3(1), 17-23.

Hegazi, E.S., M.R. El-Sonbaty, M.A. Eissa, D.M. Ahmed., T.F. El-Sharony. 2007 Effect of organic and biofertilization on vegetative growth and flowering of Picual olive trees. World J. Agric. Sci., 3(2), 210- 217.

Higa, T., F. Parrj. 1994 Beneficial and effective microorganisms for a sustainable agriculture and environment, I. Nature Farming Research Center, Atami, Japan.

Higa, T. 1995 Effective microorganisms. Their role in kyusei nature farming and sustainable agriculturc. In Jf parr, S.B. Hornick, and C.E. Whitman, Proceddings of the First International Conference of Kysei Nature farming. U.S. Department of Agriculture.

Jackson, M.L. 1973 Soil Chemical Analysis, Prentice Hall, Inc. Englewood Cliffs, N.J.

Kaloosh, A.A.1978 Factor affecting carbon dioxide evolution from soils of the Northwestern Mediterranean coast. MSc. Thesis, Fac. Of Agric. Alexandria Univ., Egypt.

Khamis, M., S M.A .Osman., A.M .Thorya. 2010 Effect of mineral and bio-NPK soil application on vegetative growth, flowering, fruiting and leaf chemical composition of young olive trees. $J$. Agric. Biological Sci. 6(1), 54-63.

Lindsay, W. L., W.A Norvell. 1978 Development of A DTPA micronutrient soil tests for zinc, iron, manganese and cupper. Soil Sci.Soc. Am. J., 42, 421-428. 
Melgar, J.C., Y. Mohamed., C. Navarro., M.A. Parra., M. Benlloch., R. Ferna' ndez-Escobar. 2008 Long-term growth and yield responses of olive trees to different irrigation regimes. Agric. water manag. 95, 968 - 972.

Ministry of Agriculture and Land Reclamation., Statistics, 2012.

Ministry of Agriculture and Land Reclamation .2011 Agricultural Statistics, pp: 2.

Mohammed, B. Kh., I. M. Noori. 2008 Effect of irrigation levels on the growth and yield of olive trees (Olea europaea L. cv.Ashrasie). J. Kirkuk University - Scientific Studies, 3, No.1.

Moriana, A., F. Orgaz, E. Fereres, M. Pastor. 2003 Yield responses of a mature olive orchard to water deficits. J. Am. Soc. Hort. Sci. 128, 425-431.

Nawaf, M. F., Y. K. Masadeh. 2006 Response of twoyear-old tree of four olive cultivars to fertilization. Am.-Erasian J. Agric. Environ. Sci., 1 (3),185-190.

Nikbakht, J., M. Taheri., M. Sakkaki. 2011 Effect of continuous deficit irrigation on yield and quality of Koronaiki olive (Oleo europaea L.) Cultivar. ICID $21^{\text {st }}, 15-23$ October 2011, Tehran, Iran.

Olk, D.C., K.G. Cassman. 1995 Reduction of potassium fixation by two humic acid fractions in vermiculitic soils. Soil Sci. Soc. Am. J. 59, 1250-1258.

Olsen, S., C. Cole., F. Watanabe., L. Dean, 1954 Estimation of available phosphorus in soils by extraction with sodium bicarbonate. USDA Circular Nr 939, US Gov. Print. Office, Washington, D.C. USA.

Olsen, S. R., F.S. Watanabe. 1965 Test of an ascorbic acid method for determining phosphorus in water and $\mathrm{NaHCO} 3$ extracts from soil. Soil Sci. Soc. Amer. Proc. 29, 677-678

Osman, S. M. 2010 Effect of mineral, bio-NPK soil application of young olive trees and foliar fertilization on leaf and shoot chemical composition. J. Agric. Biological Sci., 6(3), 311-318.

Osman, S.M., I.E. Abd El-Rhman. 2010 Effect of organic and bio $\mathrm{N}$-fertilization on growth, productivity of fig tree (Ficus Carica, L.). J. Agric. Biological Sci., 6(3), 3195-328.

Page, A.L., R.H. Miller, D.R. Keeny. 1982 Methods of Soil Analysis, Part 2:Chemical and Microbiological properties. Am. Soc. Agron, Madison, Wisconsin, USA.

Palese, A. M., V. Nuzzo., F. Favati., A. Pietrafesa., G. Celano., C. Xiloyannis. 2010 Effects of water deficit on the vegetative response, yield and oil quality of olive trees (Olea europaea L., cv Coratina) grown under intensive cultivation. Sci. Horti. 125, 222-229.

Patumi, M., R. d'Andria, V. Marsilio, G. Fontanazza, G. Morelli, B. Lanza. 2002 Olive and Olive oil quality after intensive monocone olive growing (Olea europaea L., cv. Kalamata) in different irrigation regimes. Food Chem. 77, 27-34.

Rahil, M. and F. Jabi (2015) Effects of supplementary irrigation plus humic acid application on olive production. Inter. J. Plant Soil Sci. 4,1-7.

Sardans, J., J. Penuelas. 2005 Drought decreases soil enzyme activity in a Mediterranean Quercus ilex L. forest, Soil Biol. Biochem., 37, 455-461.

SAS Institute (1988) PC - SAS users guide. Statistics. SAS Inst., Cary, NC.

Scholander, P.F., H.T. Hammel, E.T. Bradstreet, E.A. Hemmingeen. 1965 Sap pressure in vascular plants. Sci. 148, 339-346.

Shaheen, M. A., A. A. Hegazi., I. S. A. Hmmam. 2011 Effect of water stress on vegetative characteristics and leaves chemical constituents of some transplants olive cultivars. Am.-Eurasian J. Agric. Environ. Sci. 11 (5), 663-670.

Subba-Rao, N.S. 1991. Biofertilizers in Agriculture. Mohan Pcimlani for Oxford \& IBH. Darya Ganj, New Delhi.

Tabatabai, M.A. 1994 Soil Enzymes. pp. 775-833. In R.W. Weaver (Ed) Method of Soil Analysis Parts 2. Microbiological and Biochemical properties. $3^{\text {rd }}$ Ed. Soil Sci. Soc. Am. Madison, Wisconsin, USA.

Woodman, A.G. 1941 Extraction Methods, Soxhlet Fat Extraction Food Analysis, Typical Methods and Interpretation of Results. McGraw- Hill, New York, pp: 607.

Wood, C.W., P.W.Tracy, D.W. Reeves, K.L Edmisten. 1992 Determination of cotton nitrogen status with hand held chlorophyllmeter. J. Plant Nutr. 15,1439-1442.

Xiloyannis C., G. Celano., A.M. Palese., B. Dichio., V. Nuzzo. 2000 Mineral nutrient uptake from the soil in irrigated olive trees, cultivar Coratina, over six years after planting. Acta Horticult. 586.

Yousef. R. Aml, M. Hala S. Emam and M.M.S. Saleh, 2011. Olive seedlings growth as affected by humic and amino acids, macro and trace elements application. Agric. Biol. J. N. Am. 2 (7), 1101-1107.

(Received: $2 / 2 / 2019$;

accepted:24/3/2019)

Egypt. J. Soil. Sci. 59, No. 1 (2019) 


\section{تاثير معاملات الرى فى وجود التسميد العضوى او الحيوى على أشجار الزيتون

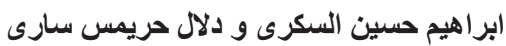

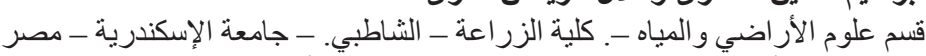

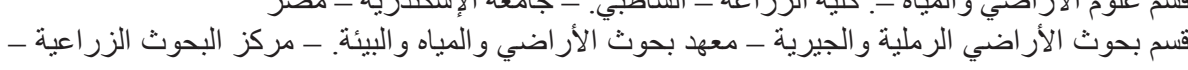

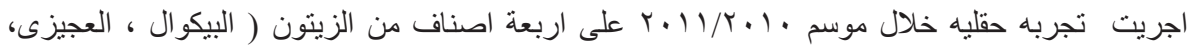

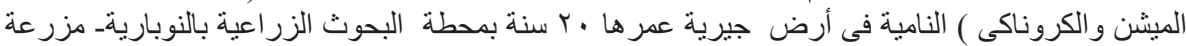

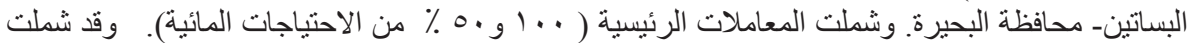

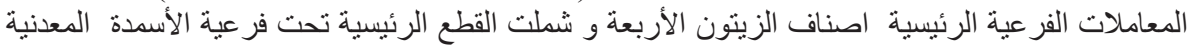

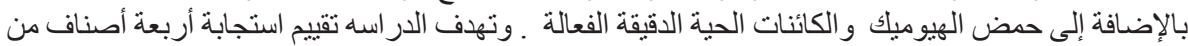

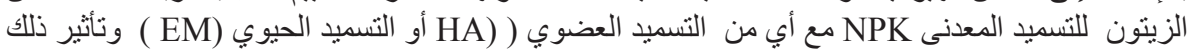

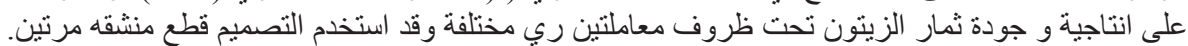

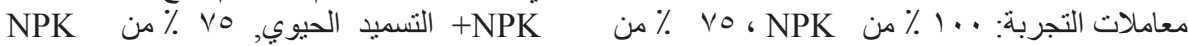

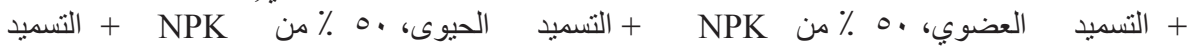

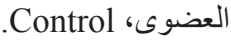

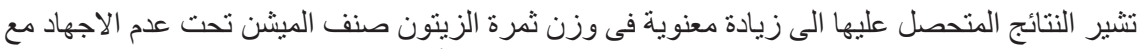

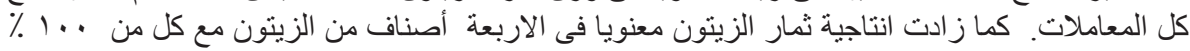

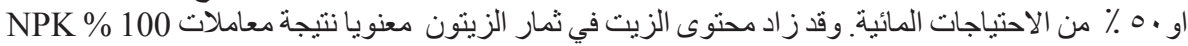

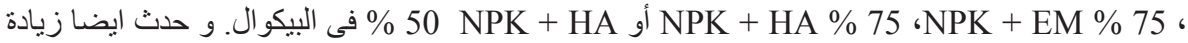

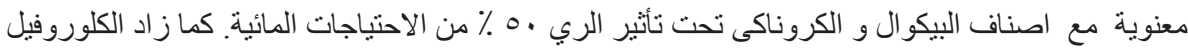

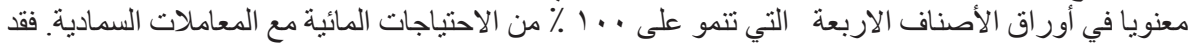

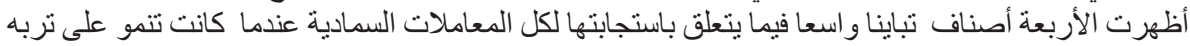

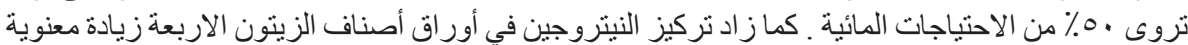

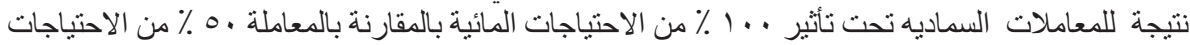

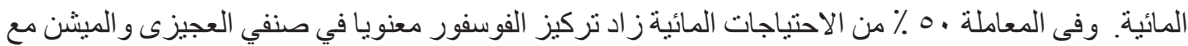

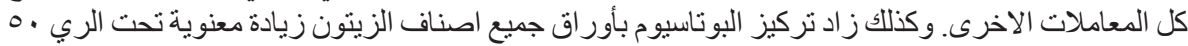

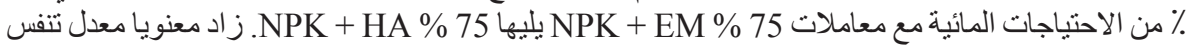

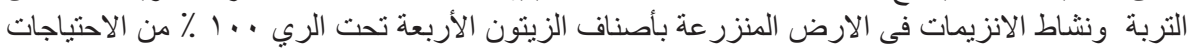

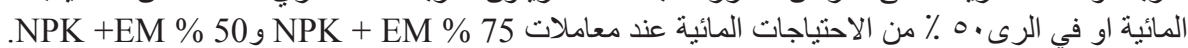

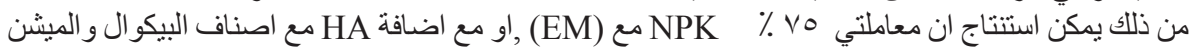

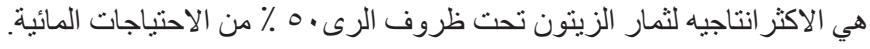

